\title{
Charakterystyka mineralogiczna faz metalicznych z miedziowych żużli hutniczych Starego Zagłębia Miedziowego
}

\author{
Katarzyna Kądziołka ${ }^{1}$, Jakub Kierczak ${ }^{1}$, Anna Pietranik ${ }^{1}$
}

\begin{abstract}
Mineralogical characteristics of metallic phases in copper slags from the Old Copper Basin, Poland. Prz. Geol., 67: 164-166; doi: $10.7306 / 2019.9$

A b s t r a c t. Metallic phases (sulphides, metallic compounds and metals), constitute critical components of metallurgical slags as they concentrate most of the potentially toxic metals occurring within smelting wastes. For this reason, a detailed characterization of the metal-rich phases is crucial for proper estimation of environmental threat resulting from slags deposition. Metallic phases observed in slags were transformed from the original ore minerals during metal smelting, and they constitute an interesting field for observations of sulphides and metals susceptibility to temperature and chemistry changes. In this study, we observed that compositions similar to sulphide minerals (e.g. bornite, chalcocite, pyrrhotite) are common, but they always appear in specific sets. We distinguished 3 general types of metallic phases: copper-iron-sulphur (among which the following subtypes appear: bornite-pyrrhotite, chalcocite, and chalcopyrite, all of these with various exsolutions), metallic copper and iron-phosphorous (Fe-P) type. Among all the distinguished types, $\mathrm{Fe}_{4} P$ proved to be most resistant to weathering whereas the $\mathrm{Cu}-\mathrm{Fe}$-S assemblage was altered strongly when not surrounded by glass or crystalline phases. Observations revealed that iron-rich metallic phases tended to appear in amorphous slags and copper-rich phases occurring within crystalline samples.
\end{abstract}

Keywords: copper slags, metallic phases, sulphides, exsolutions, weathering

Stosowanie metod petrologicznych do badania obiektów niemieszczących się w definicji skały jest prowadzone z powodzeniem od ponad 50 lat. Wśród tego typu materiałów znajdują się także żużle hutnicze, powstające $\mathrm{w}$ wyniku gęstościowej separacji stopu w piecu hutniczym na koncentrat metalu i odpad - ubogi w metale stop krzemianowy - żużel. Jednak, szczególnie w czasach historycznych, efektywność separacji metali od pozostałych składników stopu była na niskim poziomie. $Z$ tego powodu w żużlach zostały zachowane zróżnicowane fazy metaliczne, wśród których występują związki metali, metale „czyste", a także fazy składem chemicznym przypominające naturalne siarczki. Fazy metaliczne są wskaźnikiem efektywności procesu hutniczego, dokumentującym udział metalu, którego nie udało się odzyskać z rudy. Pod względem środowiskowym stanowią najważniejszy składnik żużli hutniczych, ponieważ jakkolwiek ich udział objętościowy nie przekracza najczęściej $1 \%$ składu modalnego, fazy te koncentrują w sobie wysokie zawartości potencjalnie szkodliwych metali. W wyniku wietrzenia metale są uwalniane z żużli, powodując zanieczyszczenie składników środowiska przyrodniczego, w szczególności gleb i wód powierzchniowych (np. Kierczak i in., 2013). W ostatnich latach wzrosła świadomość istnienia związku pomiędzy charakterem wiązania metali w żużlach, a zagrożeniem środowiskowym związanym z ich niekontrolowaną depozycją w warunkach powierzchniowych (np. Muszer, 1996; Tyszka i in., 2018). Prowadzonych jest wiele badań, dzięki którym zostaną lepiej wyjaśnione procesy ługowania jonów metali z próbek żużli w zależności od ich struktury krystalicznej (np. Potysz i in., 2018) oraz od warunków środowiska ich zalegania, np. pH, Eh (Jonczy, 2012). Mimo to zagadnienie mineralogicznego zróżnicowania faz metalicznych w żużlach, które rzadko - jak zostanie tu wykazane - są homogeniczne, wciąż jest podejmowane w niewielu pracach.

Celem przeprowadzonych analiz było rozpoznanie form wiązania metali w badanych próbkach żużli hutniczych, a w konsekwencji wyróżnienie preferowanych związków fazowych, wskazanie faz metalicznych najsilniej podatnych na wtórne przeobrażenia i uwalnianie szkodliwych pierwiastków, a także obserwacje przeobrażeń, które zaszły w siarczkach podczas wytopu w porównaniu z pierwotnymi minerałami rudnymi.

\section{TEO GEOLOGICZNE}

Próbki skał i żużli hutniczych zostały pobrane na terenie dawnego ośrodka hutniczego w Starym Zagłębiu Miedziowym. Badany obszar znajduje się w synklinorium północnosudeckim, na południowo-wschodnim skraju niecki leszczyńskiej w okolicy Złotoryi. Występujące tu, w utworach cechsztynu, pokłady miedzi są porównywalne ze złożami miedzi na monoklinie przedsudeckiej, w tzw. Nowym Zagłębiu Miedziowym, gdzie głównymi minerałami rudnymi sa: chalkozyn, digenit, kowelin, bornit i chalkopiryt (Sawłowicz, 1990, 1992; Kucha, 2007; Piestrzyński, 2007). Mineralizacja miedziowa występuje przede wszystkim w marglach i łupkach, które w XIX w. były poddawane intensywnej eksploatacji związanej z funkcjonowaniem kopalni i huty „Ciche Szczęście”. Przez niecałe 100 lat jej działalności w okolicy zostały zdeponowane duże ilości żużli hutniczych, których amorficzne (szkliste) i krystaliczne próbki poddano obserwacjom.

\footnotetext{
${ }^{1}$ Instytut Nauk Geologicznych, Uniwersytet Wrocławski, P1. Maksa Borna 9, 50-204 Wrocław; katarzyna.kadziolka2@uwr.edu.pl, jakub.kierczak@uwr.edu.pl, anna.pietranik@uwr.edu.pl
} 


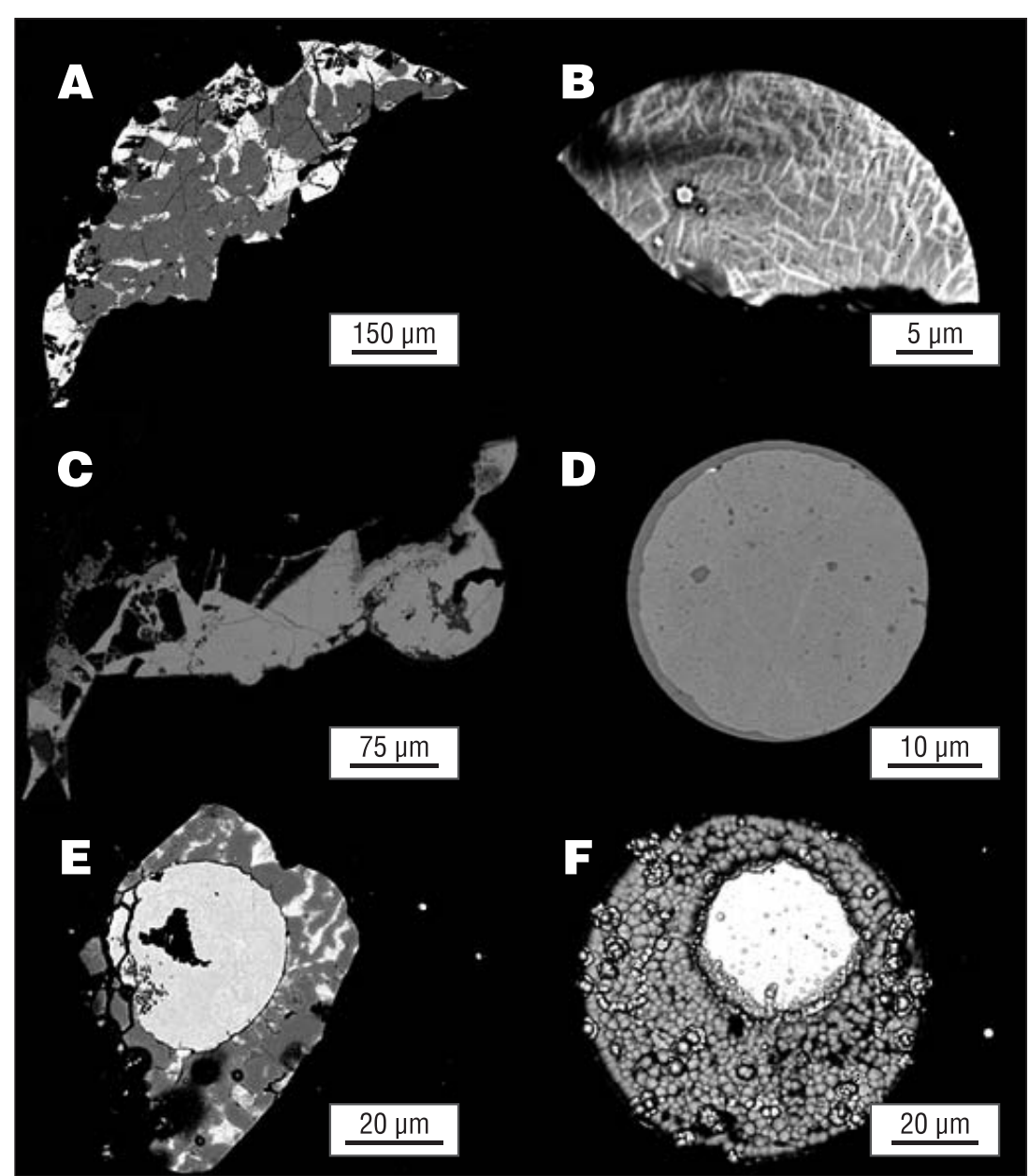

Ryc. 1. Zdjęcia BSE faz metalicznych rozpoznanych w żużlach hutniczych z niecki leszczyńskiej. A - bornit i pirotyn, B - chalkozyn z liniowymi odmieszaniami, $\mathbf{C}$ - miedź metaliczna z otoczką o składzie chalkozynu, D - chalkopiryt, $\mathbf{E}$ - faza żelazowo-fosforowa (Fe-P), $\mathbf{F}$ - ślady wietrzenia strefy siarczkowej (w centrum znajduje się niezmieniona faza żelazowa)

Fig. 1. BSE images of metallic phases distinguished in metallurgical slags from the Leszczyna Basin. A - bornite and pyrrhotite, $\mathbf{B}$ - chalcocite with linear exsolutions, $\mathbf{C}$ - chalcopyrite, $\mathbf{D}$ - metallic copper surrounded by chalcocite, $\mathbf{E}$ - iron-phosphorous type (Fe-P), $\mathbf{F}$ - weathering of sulphide-type zone (with unaltered iron phase in the center)

C - o składzie chalkopirytu (ryc. 1C). W podtypie A można zaobserwować chaotycznie rozmieszczone strefy niehomogeniczne o składzie bornitu $\left(\mathrm{Cu}_{5} \mathrm{FeS}_{4}\right)$ i homogeniczne o składzie pirotynu $\left(\mathrm{Fe}_{(1-\mathrm{x})} \mathrm{S}\right)$, ze zbliżonym udziałem objętościowym. Fazy należące do podtypu B charakteryzują się niewielkim rozmiarem i licznymi odmieszaniami oraz drobnymi $(1-10 \mu \mathrm{m})$ wrostkami $\mathrm{Cu}, \mathrm{Ag}, \mathrm{Pb}$ i Ni. Odmieszania mają charakter myrmekitopodobnych, wydłużonych, prostych lamel, przecinających się pod kątem zbliżonym do prostego. Podtyp C jest najbardziej homogeniczny, odmieszania występują tu jedynie w strefach spękań.

Parageneza miedzi metalicznej (ryc. 1D) jest reprezentowana przez sferule zwykle niewielkich rozmiarów $(5-20 \mu \mathrm{m})$, posiadające niekiedy wąską otoczkę o składzie chalkozynu. Mimo niewielkiej średnicy, typ ten ma duże znaczenie, ponieważ drobne sferule są licznie rozproszone w tle próbek i powszechnie występują w żużlach amorficznych i krystalicznych.

Parageneza żelazowo-fosforowa (ryc. 1E) jest reprezentowana przez osobniki zbudowane w centralnej części z żelaza, $\mathrm{z}$ dodatkiem fosforu, a w otoczkach $\mathrm{z}$ niehomogenicznych faz o składzie bornitu i pirotynu. Obie części fazy mają podobny udział objętościowy. Uśredniony skład chemiczny centralnej strefy można przedstawić jako $\mathrm{Fe}_{4} \mathrm{P}$, jednak miejscami zaobserwowano odmieszania wykazujące podwyższoną koncentrację fosforu. Rozmiar ziarn przekracza często $100 \mu \mathrm{m}$.

\section{ZMIENNOŚĆ CHEMICZNA}

Jakkolwiek skład chemiczny nie pozo-

\section{ZMIENNOŚĆ FAZOWA}

W badanych żużlach zostały zidentyfikowane fazy metaliczne o składzie chemicznym analogicznym do minerałów rudnych, takich jak: bornit, chalkopiryt, chalkozyn, digenit, pirotyn czy kupryt. Ponadto stwierdzono obecność faz będących mieszaniną metalu i niemetalu, tj. żelaza i fosforu $\left(\mathrm{Fe}_{4} \mathrm{P}\right)$ oraz ,czystych” kropli miedzi i żelaza. Fazy metaliczne (z wyjątkiem indywidualnie występujących faz $\mathrm{Cu}$ i $\mathrm{Fe}$ ) tworzą charakterystyczne paragenezy fazowe. Na podstawie obserwacji mikroskopowych i analiz chemicznych w mikroobszarze wyróżniono trzy dominujące typy paragenez, nazwane od dominujących pierwiastków: miedziowo-żelazowo-siarkowa ( $\mathrm{Cu}-\mathrm{Fe}-\mathrm{S})$, miedziowa ( $\mathrm{Cu}$ - miedź metaliczna) i żelazowo-fosforowa (Fe-P).

Parageneza Cu-Fe-S stanowi najbardziej złożoną z wydzielonych grup fazowych. Znajdują się w niej trzy podtypy: A - o składzie przypominającym bornit i pirotyn (ryc. 1A), B - o składzie zbliżonym do chalkozynu (ryc. 1B) oraz stawia wątpliwości odnośnie przyporządkowania większości faz wyróżnionych w typie pierwszym $(\mathrm{Cu}-\mathrm{Fe}-\mathrm{S})$, jako analogów siarczków występujących w złożach miedzi, istnieje wyraźne zróżnicowanie w proporcjach poszczególnych pierwiastków. Bornit, który stanowi fazę dominującą objętościowo w próbkach, w złożu Polkowice charakteryzuje się uśrednionym składem: $\mathrm{Cu}_{4.76} \mathrm{Fe}_{1.24} \mathrm{~S}_{4}$ (Przewoźnik i in., 2013). W żużlach zawartość miedzi i żelaza znacznie odbiega od składu chemicznego naturalnego bornitu $\left(\mathrm{Cu}_{4.04-6.32} \mathrm{Fe}_{0.621-1.33} \mathrm{~S}_{4}\right)$, a atomowy stosunek $\mathrm{Fe} / \mathrm{Cu}$ waha się w granicach $0,14-0,35$. W przypadku faz o składzie zbliżonym do chalkozynu atomowy stosunek $\mathrm{Cu} / \mathrm{S}$ mieści się w granicach 2,01-1,07, z dominacją zakresu 1,7-1,8. Przy uwzględnieniu zawartości Fe i Ag w próbkach występuje niemal pełny szereg minerałów grupy $\mathrm{Cu}-\mathrm{S}$, od chalkozynu do kowelinu, z dominacją anilitu. $\mathrm{Z}$ kolei fazy przypominające składem pirotyn zawierają $\mathrm{w}$ swojej strukturze do 6\% wagowych miedzi.

Prezentowane badania pozwoliły wykazać, że fazy wzbogacone w żelazo występują najczęściej w żużlach 

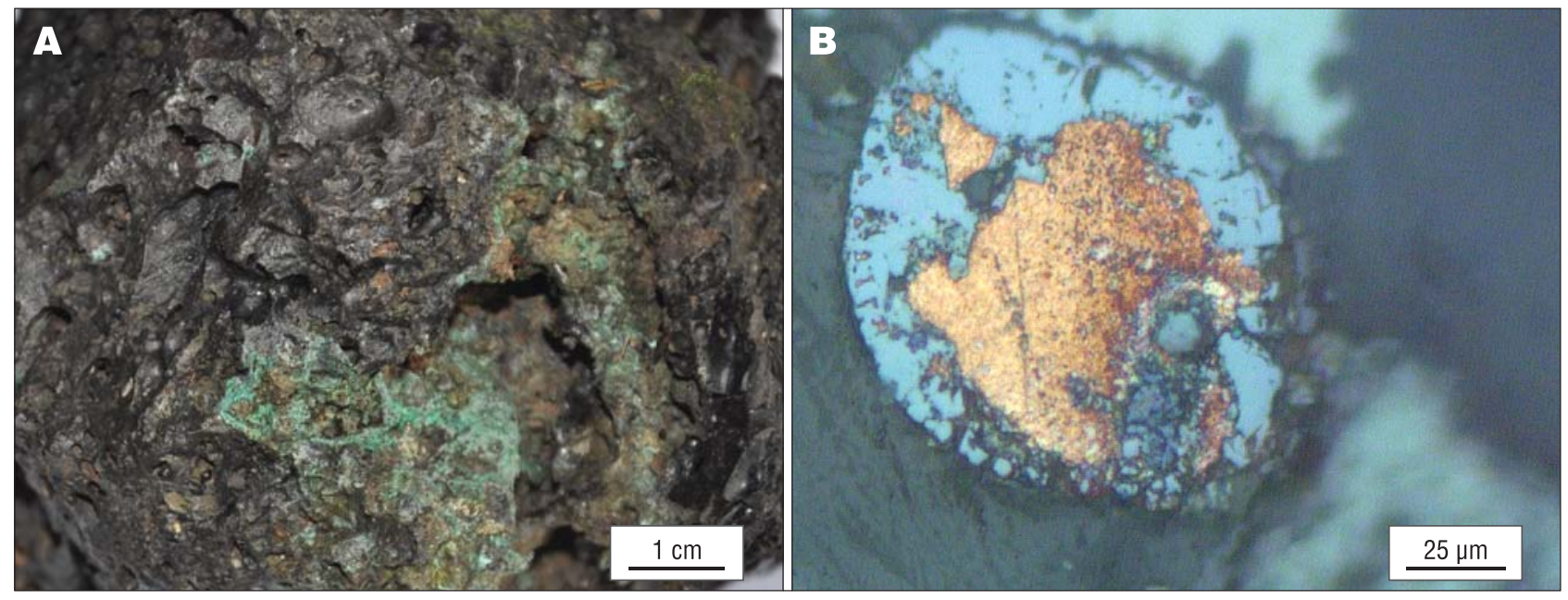

Ryc. 2. A - faza wtórna krystalizująca na powierzchni żużla (brochantyt, rozpoznany za pomocą analizy XRD), B - fotografia w świetle odbitym - utlenianie miedzi (pomarańczowa) do kuprytu (niebieski)

Fig. 2. A - secondary phase (brochantite, recognised with the XRD analysis) crystallizing on the slag surface, $\mathbf{B}$ - photomicrograph of copper (orange) and cuprite (blue) in a slag sample, reflected light

amorficznych, a bogate w miedź dominują w żużlach krystalicznych.

Zbadane fazy metaliczne uległy przeobrażeniom, o czym świadczą licznie rozpoznane ślady wietrzenia. W wyniku ekspozycji na warunki środowiskowe nastąpiło utlenianie miedzi do kuprytu, utworzenie delafosytu oraz warstwy brochantytu na powierzchni żużli (ryc. 2). Dodatkowo podczas prowadzonych badań zaobserwowano ślady silnych przemian stref $\mathrm{Cu}-\mathrm{Fe}-\mathrm{S}$. Na rycinie $1 \mathrm{~F}$ została zaprezentowana faza Fe-P z otoczką o składzie $\mathrm{Cu}-\mathrm{Fe}-\mathrm{S}$, gdzie doszło do wytworzenia charakterystycznych, wzbogaconych w siarkę, wypukłych form w kształcie kalafiora. W części żelazistej opisane przemiany nie są widoczne. W przypadku podtypu A paragenezy Cu-Fe-S zmiany wietrzeniowe sa najczęściej zlokalizowane na granicy stref o składzie pirotynu i bornitu.

\section{WNIOSKI}

Przeprowadzone obserwacje pozwoliły wykazać obecność zróżnicowanych mineralogicznie faz metalicznych w żużlach hutniczych Starego Zagłębia Miedziowego. Rozpoznane w żużlach paragenezy fazowe przypominają paragenezy mineralne występujące $w$ złożach miedzi na monoklinie przedsudeckiej i w niecce północnosudeckiej. Wydaje się jednak, że w wyniku wysokotemperaturowego procesu wytopu metalu $\mathrm{z}$ rud, nastąpiła agregacja metali w fazy rozmiarem często przekraczające $100 \mu \mathrm{m}$, z jednoczesnym rozdziałem wewnętrznym na strefy o różnym składzie chemicznym. Podczas chłodzenia zostały wytworzone liczne odmieszania, w których zostały skoncentrowane pierwiastki metaliczne $(\mathrm{Cu}, \mathrm{Ag}, \mathrm{Pb}, \mathrm{Fe})$. Proces wytopu metalu lub późniejszego chłodzenia stopu sprzyjał tworzeniu skomplikowanych związków metalicznych, na co wskazuje zestaw form i faz, takich jak: fazy o składzie bornitu i pirotynu, fazy o składzie chalkozynu z silnie zróżnicowanymi proporcjami $\mathrm{Cu} / \mathrm{S}$ w ramach jednego osobnika czy pagareneza żelazisto-fosforowa $\mathrm{z}$ pirotynem i bornitem, których skład chemiczny jest rozbudowany względem pierwotnej mineralizacji miedziowej. Fazy o składzie $\mathrm{Cu}-\mathrm{Fe}-\mathrm{S}$ wykazują największą podatność na procesy subaeralnego wietrzenia.

Autorzy wyrażają serdeczne podziękowania za wnikliwą i konstruktywną recenzję tekstu prof. Sławomirowi Oszczepalskiemu. Praca naukowa była finansowana ze środków budżetowych na naukę w latach 2016-2018, jako projekt badawczy w ramach programu Diamentowy Grant.

\section{LITERATURA}

JONCZY I. 2012 - Formy występowania wybranych metali w żużlach hutniczych na tle ich właściwości geochemicznych. Gospod. Sur. Mineral., 28 (1): 63-75.

KIERCZAK J., POTYSZ A., PIETRANIK A., TYSZKA R., MODELSKA M., NÉEL C., ETTLER V., MIHALJEVIČ M. 2013 - Environmental impact of the historical Cu smelting in the Rudawy Janowickie Mountains (south-western Poland). J. Geochem. Exp., 124: 183-194.

KUCHA H. 2007 - Mineralogia kruszcowa i geochemia ciała rudnego złoża Lubin-Sieroszowice. Biul. Państw. Inst. Geol., 423: 77-94.

MUSZER A. 1996 - Charakterystyka petrograficzno-mineralogiczna żużli metalurgicznych z huty Miedzi Głogów. Fizykochem. Prob. Mineralurgii, 30: 193-205.

PIESTRZYŃSKI A. 2007 - Okruszcowanie. [W:] Piestrzyński A., Banaszak A., Zaleska-Kuczmierczyk M. (red.), Monografia KGHM Polska Miedź SA. Allexim sp.z o.o., Wrocław: 167-197.

POTYSZ A. KIERCZAK J., PIETRANIK A., KĄDZIOŁKA K. 2018 Mineralogical, geochemical, and leaching study of historical $\mathrm{Cu}$-slags issued from processing of the Zechstein formation (Old Copper Basin, southwestern Poland). Appl. Geochem., 98: 22-35.

PRZEWOŹNIK J., ŻUKROWSKI J., GONDEK Ł., GĄSKA K., LEMAŃSKI A., KAPUSTA C., PIESTRZYŃSKI A. 2013 - Structural, magnetic, and Mössbauer effect studies of bornite. Nukleonika, 58 (1): 43-46.

SAWŁOWICZ Z. 1990 - Primary copper sulphides from the Kupferschiefer, Poland. Mineral. Dep., 25: 262-271.

SAWŁOWICZ Z. 1992 - Primary sulphide mineralization in $\mathrm{Cu}-\mathrm{Fe}-\mathrm{S}$ zones of Kupferscheifer, Fore-Sudetic monocline, Poland. Transactions of the Institution of mining and metallurgy, 101: B1-B8.

TYSZKA R., PIETRANIK A., KIERCZAK J., ZIELIŃSKI G., DARLING J. 2018 - Cadmium distribution in Pb-Zn slags from Upper Silesia, Poland: Implications for cadmium mobility from slag phases to the environment. J. Geochem. Exp., 186: 215-224. 